Media Industries 6.1 (2019)

\title{
Kim Kimble: Race, Gender, and the Celebrity Hairstylist
}

\author{
Priscilla Peña Ovalle ${ }^{1}$ \\ UNIVERSITY OF OREGON \\ povalle [AT] uoregon.edu
}

\begin{abstract}
This essay focuses on the creative labor of Kim Kimble, celebrity hair stylist and hair care entrepreneur, across various media platforms. Kimble has gained visibility on mainstream US film and television by styling performers like Beyoncé and starring in her own reality program, L.A. Hair (2012-2017). I argue that Kimble's identity and career-as a Black woman and third-generation hair stylist-invites us to revise racialized and gendered assumptions about "below the line" labor while also observing systemic inequities that operate in the industries of hairstyling and media production.
\end{abstract}

Keywords: Hair, Intersectionality, Labor, Performance, Reality Television

With a roster of major celebrity clients, a US cable reality show, and a line of professional styling products to her name, Kim Kimble is one of a growing number of hair care professionals best described as a "celebrity stylist," a creative practitioner with famous clientele, name recognition, and a marketable brand. The breadth of Kimble's professional experiencefrom feature films to fashion photography, live concert performances to music videos, each with their own methods and demands-is notable in and of itself. But as an African-American woman, Kimble stands out among her predominantly (white) male cohort of celebrity stylists in an otherwise female-dominant profession.

This essay focuses on Kim Kimble's creative labor and her growing legacy as a Black woman styling some of the most prominent heads of hair in US popular culture and beyond, including Beyoncé, Nicki Minaj, Mary J. Blige, Oprah, and Shakira. Using key moments of Kimble's professional history, interviews, and one season of the reality show L.A. Hair (2012-2017), I argue that Kim Kimble's career invites us to revise racialized and gendered assumptions about "below the line" labor. The specificity of Kimble's identity-as a Black woman and 
"third-generation hair stylist" ${ }^{2}$ whose career is anchored by a multi-generational, matrilineal knowledge of the profession-provides a unique opportunity to observe the systemic inequities operating in the hairstyling and media production industries. ${ }^{3}$

Styling hair is a predominantly female profession; recent census data show that women make up 90.8 percent of the hairdressers, hairstylists, and cosmetologists in the United States. ${ }^{4}$ Yet, the mainstream profession disproportionately pays and celebrates (white) male stylists. Adrienne L. McLean has shown how early Hollywood makeup artists like Max Factor and the Westmores-a dynasty of brothers who ran makeup and hair departments in nearly every Hollywood studio in the early twentieth century-built retail companies and became recognizable sources for style advice in newspaper columns and salons around the country, largely bolstered by star endorsements. ${ }^{5}$ Hairstylists like Vidal Sassoon employed similar tactics in the 1960s, building product lines and using Hollywood connections for publicity. White women stylists-the majority of this workforce-have simply not enjoyed the same level of name recognition.

Trade magazines focused on the mainstream beauty industry have regularly addressed the gender disparity of celebrity stylists. In the 1990s, the official publication of the US National Hairdressers and Cosmetologists Association, American Salon, published an article that posed this question: "If 80 percent of hairdressers are women, why aren't any of them as famous as men like Vidal Sassoon?" The article, "Women on Top," cited one source who speculated that shampoo and conditioner products play a role in this inequity because these products often feature male stylists' names and are heavily promoted through advertising. ${ }^{7}$ Twenty years later, American Salon again questioned gender disparity in an article entitled "Broad City." By that point, however, the publication was able to declare that "more and more women [were] finally assuming their rightful place in positions of power and influence in the professional beauty industry" and pointed to Kim Kimble as a prominent woman in the field. ${ }^{8}$ While this trade coverage addresses the under-recognition of women by an industry in which they are demographically dominant, there is no explicit attention to racial inequities.

Coverage of Kimble in mainstream hairstyling trade magazines like American Salon or Modern Salon privilege her identity as a woman; her identity as a woman of color, however, is typically obscured or signaled through music or mentions of hair texture. For example, "Broad City" does not mention Kimble's racial identity. Instead, the American Salon article states that Kimble's products are largely "designed for women of color with various hair textures" and are suitable for "both natural hair and extensions." ${ }^{9}$ A so-called postracial ${ }^{10}$ reading of this omission might suggest that Kimble's success goes beyond her Blackness-in other words, Kimble's race isn't mentioned because it isn't relevant at this historical moment-but this logic is unsatisfactory given the article's focus on bias in the industry and use of the term "women of color" to describe potential patrons.

Given Kimble's celebrity clientele, many of whom are singers, it is no surprise that mainstream trade coverage of Kimble's career emphasizes music. But here, the focus on music also serves as a code for nonwhiteness-much in the way that the term "urban" has been used in mainstream US media to identify nonwhite markets since the 1990s. Kimble is introduced as having a client list that "teems with R\&B divas" (emphasis added) and that her hair 
care system was launched during a break from a Destiny's Child tour. ${ }^{11}$ These associations (and questionable use of language) effectively allude to race while underscoring how Kimble's status has grown with that of the nonwhite female superstars she styles-stars who have themselves gained greater visibility in the white-dominant US media landscape, often through music videos. Because Kimble's name recognition is built on consistent collaboration with prominent women of color in US popular culture, it is important to understand how her labor might be valorized or denigrated differently depending on the community context.

In the Black community, female stylists have long been celebrated. Because cosmetology was one of the few, early professions within which Black female entrepreneurs could thrive in the United States, it was quickly aligned with progress and uplift. As Julia Kirk Blackwelder notes in Styling Jim Crow: African American Beauty Training During Segregation, the beauty industry was "one of the few occupational options away from field, factory, and kitchen" available to nonwhite women in the early half of the twentieth century. ${ }^{12}$ By creating and marketing products or building beauty schools, women like Annie Malone and Madame C.J. Walker established business empires by overcoming the financial and social barriers facing (Black) women at the time. ${ }^{13}$ Beauty education was "as much a component of the client's selfimprovement as was advancement in literacy or occupational skills." ${ }^{14}$ So in addition to technical skills, beauty schools often promoted Black self-sufficiency, trained women how to "survive under Jim Crow," and played significant roles in the business and political lives of African American communities. ${ }^{15}$

This history of Black female stylist-entrepreneurs provides an important backdrop for Kimble's multigenerational education. ${ }^{16}$ Kimble's career builds on her mother's and grandmother's knowledge of hair, bolstered by training at the Vidal Sassoon Academy and the Dudley Cosmetology University in North Carolina. ${ }^{17}$ To better understand Kimble's familial and industrial influences, I interviewed Jas Kimble, Kim's mother and a cast member on L.A. Hair. Jas spoke about her own mother's work as a stylist: Jas' mother preferred to earn a steady factory paycheck and do hair at home, on the side, rather than start a business herself. Instead, she encouraged Jas to pursue hairstyling as a profession. Jas soon owned a salon in Chicago, but eventually moved to Los Angeles in pursuit of film work-despite the fact that she wasn't sure how a Black hairstylist might get into the industry. ${ }^{18}$ Membership in the Make-Up Artists \& Hair Stylists Guild (International Alliance of Theatrical Stage Employees, Local 706) was crucial for access to film jobs, but the industry had only begun to integrate Black stylists in the late twentieth century. It was not until 1968 that Ann Wadlington joined Local 706, the first African-American person to do so. ${ }^{19}$ Despite the fact that Jas worked for Wadlington in an LA salon, she could not break into media production herself. Instead, Jas supported Kim's growing talent, describing her daughter's career as an extension of their family history within the industry: "What [Kim's] created in those products is the experience of my mother and me. She put them all together. She wants to be Vidal Sassoon with a Madame C.J. Walker twist." 20 Both Jas and Kim pursued professional training at the Sassoon Academy and spoke at length about Sassoon's styles and methods, underscoring the impact of his techniques on their creative approach and professional development. By connecting Sassoon and Walker, Jas frames Kim as a professional with mainstream training (Sassoon) as well as specialized skills and marketing strategies (Walker). 
The matrilineal experiences of Kimble's mother and grandmother anchored her artistic talent and provided an important road map for her career. Kim opened her first salon in L.A.-named Phaze II, a sequel to Jas' Chicago salon-in 1995. But she was inspired by her mother's interest in film and quickly sought opportunities beyond salon work. Soon after opening Phaze II, Kim volunteered to do hair for a church charity stage production. The show, produced by the film director Robert Townsend, gave Kim an industry connection by way of his assistant. Kim's persistence ultimately led to her first film credit on B.A.P.S. (1997), directed by Townsend and starring Halle Berry. ${ }^{21}$ Kim was already a thriving stylist with her own salon, but B.A.P.S. proved to be an invaluable learning experience that created new opportunities for her (and her mother).

Given Kimble's current clientele, it's fitting that her first feature film production would be about two hairstylists focused on auditioning for a music video. In B.A.P.S., two waitresses from Georgia (Berry, with Natalie Desselle) head to Los Angeles to audition for a Heavy D music video on MTV; their goal is to earn the video's US\$10,000 cash prize so they can open a salon and restaurant. Kimble produced the fantastical wigs worn by Berry and Desselle, showcasing her spectacular artistic and technical skills honed after years of winning Bronner Bros. International Beauty Show hair battles (Figure 1).

The film B.A.P.S. showcases Kimble's creative talents, but the production tested her business savvy, ingenuity, and mettle. In addition to earning credit on a Townsend/Berry film, Kimble also gained invaluable experience by solving the production's unique creative and technical challenges. Kim Kimble recalls,

I had to create several [wigs]. I had an assembly line of hair, because we had to have some that looked good, some that looked like they were weathered. Then I had to do some for the stand-in and for the stunt double. I also had a backup in case something happened. That was my introduction [to film production]. It was a lot. I had to learn quickly about film. I didn't know anything about it. ${ }^{22}$

Heeding her mother's advice, Kimble negotiated to ensure that her work on B.A.P.S. would facilitate union membership (a few years later, Kim helped Jas join as well). ${ }^{23}$ Kim notes, "That was my first project. I said, 'I want to get in the union. I want to be an official, legitimate hairstylist

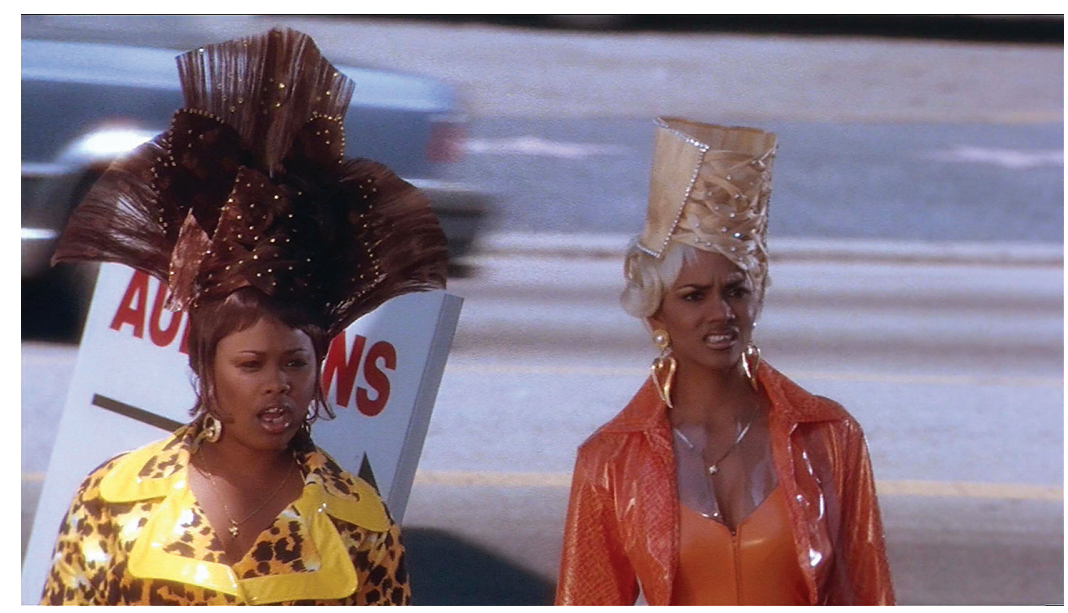

Figure 1. Natalie Desselle (left) and Halle Berry (right) in B.A.P.S. (1997). Hair by Kim Kimble and costumes by Ruth Carter. 
that can work on film and television.' And my career took off from there." ${ }^{24}$ Kimble began styling for film and television, but eventually worked with music artists on more freelance projects after meeting them on film sets, because "that's when a lot of music artists were transitioning into film." ${ }^{25}$ After meeting on the set of the MTV TV movie Carmen: A Hip Hopera (2001, directed by Townsend), Kimble began her long-standing collaboration with Beyoncé on Austin Powers in Goldmember (2002), most recently culminating in the video album Lemonade (2016) and Beyoncé's historic performance as the first Black female headliner at Coachella in 2018.

Kimble's media career began as a new wave of nonwhite female rap, hip hop, or R\&B artists were beginning to "crossover" to mainstream US media markets in the late 1990s. Music videos-first via cable television, then via online platforms like YouTube or Vimeo-made many of these women more visible to mainstream audiences. ${ }^{26}$ Though still underrepresented, nonwhite performers like Jennifer Lopez and Beyoncé became media moguls in this period, with manes to match. ${ }^{27}$ In Black Looks: Race and Representation, bell hooks argues that Black female singers have often capitalized on sexualized stereotypes, to "either assert control over the representation or at least reap the benefits of it." ${ }^{28}$ She adds that, more recently, the "sexualized imagery for black female stars seems to be fixated on hair; it and not buttocks signifies animalistic sexuality." ${ }^{29}$ Though hooks was writing about Tina Turner and Diana Ross, the sexualized connotations of hair have become a major feature of female music video performances. My own interest in Kim Kimble began with the music video for "Beautiful Liar" (2007), in which Beyoncé and Shakira mirror each other in look and movement (Figure 2). ${ }^{30}$ The video riffs on the fact that Beyoncé and Shakira physically resemble each other: the two singers' seductive dance moves and similar hairstyles (by Kimble) underscore their interchangeably brown, feminine bodies on screen. ${ }^{31}$ This video illustrates the performative and production qualities of hair, revealing how media hairstyles function as interlocking, malleable, and marketable codes for gendered and racialized sexuality on screen.

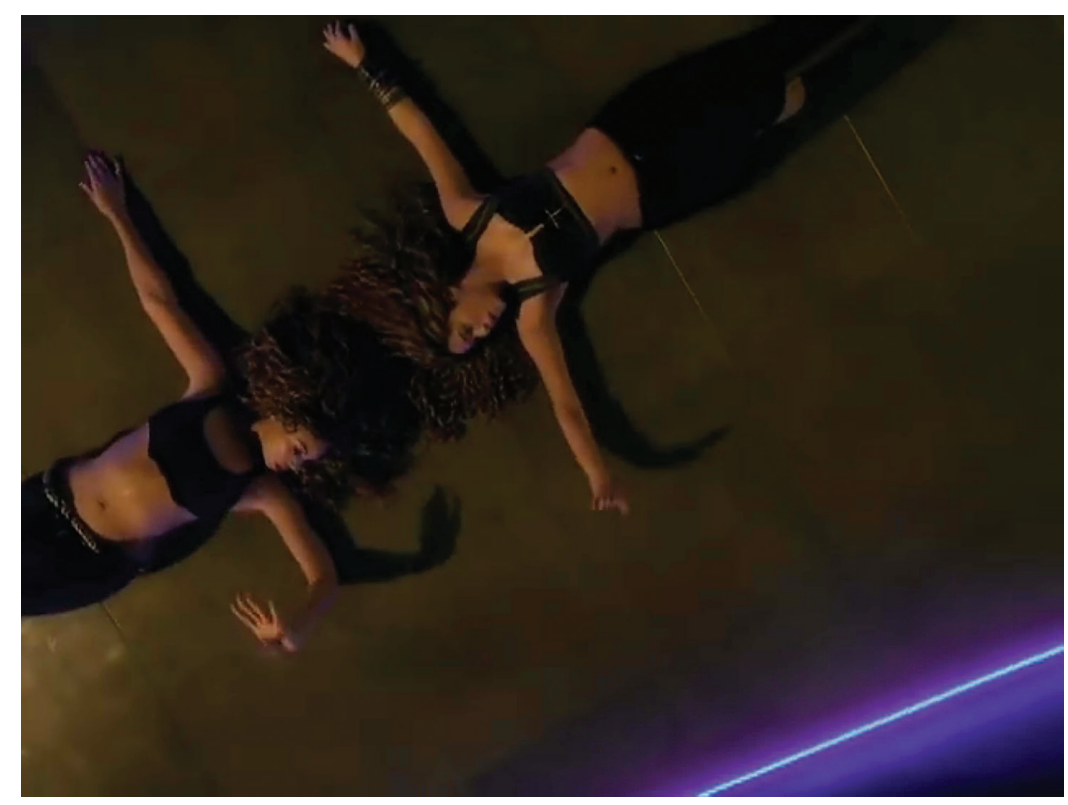

Figure 2. Beyoncé (left) and Shakira (right) in Beautiful Liar (2007). Hair by Kim Kimble. 
The strategic use of hair by nonwhite female performers like Beyoncé, Jennifer Lopez, and Shakira to access the mainstream media spotlight is a maneuver necessitated by a racist and sexist history of labor and media production practices in the United States. In the United States, hair has long been a "measure" of race; Ayana Byrd and Lori Tharps found that hair was once "considered the most telling feature of Negro status, more than the color of the skin." ${ }^{32}$ Even today, Black women's hair remains a source of discrimination in the workplace. Legal scholar Paulette Caldwell has shown how Black women are disproportionately reprimanded for wearing so-called artificial hairstyles (braids!) to work. ${ }^{33}$ By regulating Black women's hairstyles, employers and the courts that rule in their favor jeopardize women's livelihoods in the name of esthetics; these cases illustrate how the regulation of esthetics is far from benign and instead determines "who and what is valued, beautiful, and entitled to control." ${ }^{34}$ For working Black women-whether airline attendants or pop stars-hair is a measure of "legitimacy" or legibility that often determines whether or not they can "crossover' . . into mainstream American life." ${ }^{35}$ (There is one glimmer of change: In February 2019, the New York City Commission on Human Rights declared that "targeting of people based on their hair or hairstyle, at work, school or in public spaces, will now be considered racial discrimination." ${ }^{36}$ )

If-as Kobena Mercer has stated-hair is "the most tangible sign of racial difference," ${ }^{37}$ then Hollywood's historical investment in "normalcy" (i.e., whiteness) for the sake of an invisible film grammar has further entrenched racist and sexist assumptions about hair into Hollywood's symbolic and industrial systems. ${ }^{38}$ In Costume, Makeup, and Hair, Adrienne L. McLean notes that the

ideal of Hollywood's "invisible system" suggests that costume, makeup, and hair are, or should be, designed primarily to support the narrative and the actors who embody its characters rather than to loom large or draw attention to themselves on their own. ${ }^{39}$

McLean further argues that cinematic conventions of hair and makeup were designed to look "normal and natural on and off the screen," often with the support of cosmetic products. ${ }^{40}$ Though most Hollywood hair looks are manufactured for the sake of things like continuityindeed, Hollywood heavily relied on wigs until the $1960 \mathrm{~s}^{41}$ - production and performance practices that stress the ideals of "normalcy" or "invisibility" also reinforce the notion that whiteness is both natural (i.e., not "artificial") and the default human identity. ${ }^{42}$ In early Hollywood, Black women that did not fit this standard had to literally cover up their (hair) difference. ${ }^{43}$

In the contemporary period, however, music video hairstyles are designed to stand out, through look and motion. In music videos, hair can enhance choreography and act as a kind of secondary movement that punctuates dance performances on screen, thus deepening a viewer's kinetic connection to the sound and image. Another "mobile hair" trope is exemplified by the wind-blown or tumbling tresses ubiquitous to mainstream hair care commercials; female singers like Beyoncé and Lopez recreate these hair-billowing moments during live performances by standing in front of a fan. In hair care commercials, where mobile hair is de rigueur, these effects require the use of a leaf-blower or a greenscreened puppeteer. ${ }^{44}$

Once styles circulate via music videos, they are then re-circulated online via social media and the popular press, which can further enhance the performer's and celebrity stylist's 
brands. A hairstylist like Kimble-who works in both music videos and commercials-can help enhance a performer's persona and performance by styling looks that set or develop these hair trends. After Kimble styled Beyoncé with long, thin braids for the music video "Formation" (2016), she revamped the look for Nicki Minaj's appearance in the "Motorsport" video (2017). Kimble tailored the style for Minaj's personal esthetic by extending the braids to the floor and tinting them pink, leading fans to dub the look "Pink Lemonade" on social media.

Kim Kimble has long used Twitter, Instagram, and Facebook to promote herself, her work, and her products; this early adoption of social media has been critical to her celebrity branding and entrepreneurial endeavors, but it is not without its pitfalls. In 2016, American Salon called Kimble a social media "rock star," pointing to the strength of her following on Instagram-then a respectable 281,000, now 464,000. ${ }^{45}$ But social media can sometimes highlight creative differences or exacerbate professional tensions in a very public way. Celebrity stylists build intimate relationships with their clients, but these clients are very public figures and often work with a variety of stylists, depending on the project or location. For example, Kimble has worked extensively with Beyoncé and earned sole "Hair" credit on Lemonade. But Beyoncé has other long-time stylists, like Neal Farinah, who most recently styled Beyoncé's "natural" looks for the September 2018 cover of Vogue. When Farinah cut Beyoncé's hair into a very short pixie style in 2013, the new look was quickly revealed on Instagram. The celebrity-friendly People magazine immediately sought Kimble's reaction to this event, reporting,

Kimble says her reaction upon seeing the new do on Instagram Wednesday night was more than surprised-it was emotional. "I got a little teary eyed!" she confesses. "I've been working for her so long, she has this beautiful long hair and it's hard to grow hair out. I feel like it's my hair, I work so much with her. I feel a little emotional but excited for her too. Maybe I'll cut my hair off now. Short hair, don't care!"46

Kimble's investment in Beyoncé's hair underscores the creative, professional, and emotional connection that stylists can build with their clients. But these artistic investments can sometimes lead to professional tensions. In 2018, Kimble and Tokyo Stylez, a newer-generation stylist with 1.1 million Instagram followers, engaged in a heated Instagram exchange. After Tokyo Stylez made a snide comment about Kimble's then recent work with Nicki Minaj, Kimble responded by seemingly dismissing Tokyo Stylez as an unlicensed stylist. ${ }^{47}$ Kimble's reply defends her hard-won legitimization as a unionized, licensed, celebrity stylist; unfortunately, in this public exchange, it seems at odds with the informal, "kitchen" history of Black hairstyling. ${ }^{48}$

Herein lies the duality of the celebrity stylist: historically, their labor is performed behind the scenes or "below the line," but this work is critical to the performers they style and facilitates their own prestige and public-facing persona as celebrity stylists. Kimble's work may adorn the heads of powerhouse women, including the bewitching locks worn by Oprah Winfrey and Mindy Kaling in the feature film Wrinkle in Time (2018), but her labor on their behalf would be obscured if she had not built her brand and career through self-promotion and social media. When I interviewed Kim Kimble about early career challenges, she talked about the misperceptions she faced when she arrived on set: people tended to presume that she 
was not qualified, or that she was related to the client, or that she had no idea how a hair department worked. ${ }^{49}$ Kimble's name recognition has since abated such unfair treatment, but racist and sexist assumptions about Black (female) representation, labor, and marketability remain.$^{50}$ Kimble's rise to the top of her field-as a Black female stylist working with the biggest nonwhite female celebrities in music that are similarly underrepresented in a racist and sexist media industry-reveals the range of creative, technical, and emotional labor required to earn and work in the spotlight as a hairstylist.

Despite the access to new job opportunities, community, and protections that joining a union may afford, media hairstylists are often undervalued given the hierarchical practices of Hollywood production, which forces a false binary of "above the line" and "below the line" labor. Miranda J. Banks summarizes how practitioner positions are socially and industrially constructed on set, typically associating "imagination, artistry, and inventiveness" with above the line positions while denigrating below the line positions as little more than "craftspeople or technicians, people who work with their hands." 11 These uneven categorizations-which impact everything from revenues to one's sense of creative ownership ${ }^{52}$-are exacerbated when certain kinds of below the line labor are further subordinated due to specific gender associations. ${ }^{53}$ In the context of a Hollywood production, positions like costuming are often gendered as feminine and consequently "devalued in relation to professions of, arguably, comparable import that are majority male." ${ }^{54}$ As Vicki Mayer's work on below the line workers in the television industry shows, once certain positions are gendered and/or racialized, it is difficult to erase the presumed, subordinated status of these positions. ${ }^{55}$

Styling hair is an intimate labor practice that is artistic and technical, practical and emotional; yet, as a below the line department, hair is often disregarded because it is a familiar, female dominant production department that is aligned with the body. ${ }^{56}$ McLean notes that the personal, everyday nature of things like costuming and hair-perceived as little more than clothes or something that (usually) grows on human heads-reifies their purported lack of value. ${ }^{57}$ While men "once dominated studio makeup departments and women handled hair," women now dominate both departments-but these gendered divisions seem to linger in terms of pay disparity. ${ }^{58}$ In The Managed Hand: Race, Gender, and the Body in Beauty Service Work, Miliann Kang builds on Arlie Hochschild's concept of "emotional labor" to highlight how the "body labor" of beauty services is often dismissed as unskilled, "when in fact beauty work entails highly skilled procedures as well as the exercise of extensive emotional labor." ${ }^{\text {"9 }}$ Such cumulative perceptions may have contributed to the Academy of Motion Picture Arts and Sciences' continued dismissal of the field; when hairstyling was finally admitted as an award category in the 1990s, it was awkwardly smashed into the "Best Makeup" Oscar.

Hairstylists like Kimble are no less beholden to the artistic and industrial demands of production: every detail must be considered when styling hair, from choreography to character to camera movement, from weather conditions to the impact a look may have on a performer's persona. Hair that does not function technically can ruin a shot during a dance number or special effects setup; a look that doesn't feel right for the performer can wreck their confidence or character. As artists, hairstylists must ensure their creations perform esthetically while their technical skills ensure that these designs perform equally well in stillness and motion. Such demands are especially true for stylists working with high-energy performers on music videos and commercials. These stylists must meet the technical and performance 
demands of robust movement-such as the "hair-ography" of music videos or the unrealistic hair esthetics of "shine" and "bounce" in hair care commercials-while also delivering the kind of trend-setting artistry that fans will want to copy. Furthermore, the emotional labor of the stylist-client relationship can be incredibly intimate and impact performance, since stylists often have regular on-set contact with a performer in the crucial moments before a scene or show. ${ }^{60}$ And yet, the creative, technical, and emotional labor of stylists is undervalued and overlooked.

For five seasons, Kim Kimble starred in the popular reality television series L.A. Hair (20122017), which chronicles Kimble running Kimble Hair Studio, her West Hollywood, California salon. ${ }^{61}$ The structure of L.A. Hair is indebted to Blow Out (2004-2006), which starred celebrity stylist Jonathan Antin and ostensibly launched a trend of hair-themed reality programs produced in the United States. Following Blow Out, a succession of similarly themed shows and spin-offs aired on US television, including Shear Genius (2007-2010), Tabitha Takes Over (2008-2013), Houston Beauty (2013), and L.A. Hair. While the formats of hair-themed shows range from competition to unscripted dramas, they have primarily aired on so-called women's or "lifestyle" channels, like Bravo, the Oprah Winfrey Network (OWN), and Lifetime. ${ }^{62}$ L.A. Hair aired on WE tv, a US cable channel owned and operated by AMC Networks. When the network launched in 2001, it branded itself as "Women's Entertainment," but soon dropped the tag to "embrace a broader audience." ${ }^{3}$ By 2016, the channel was focused on unscripted programming ${ }^{64}$ and-thanks in large part to L.A. Hair-was deemed "the No. 1 network in cable on Thursdays among African-American woman and African-American adults in the 18-49 and 25-54 [demographics]." ${ }^{65}$ Like Blow Out, which followed the launch of Antin's Beverly Hills salon and other business ventures for three seasons, the unscripted drama of L.A. Hair is anchored by the Kimble Hair Studio, where Kim styles celebrity clients, expands her brand, and manages a team of stylists with her mother, Jas, and sister, Leah. This supporting cast provides healthy doses of comedy and drama, often oscillating between being sources of solace or frustration for Kimble.

As scholars like Paulette Caldwell have argued, real-world racist notions are often displaced onto Black women's hair, so it is no surprise that a celebrity stylist reality show starring a Black woman might reveal moments of racialized gender and labor politics. ${ }^{66}$ As Racquel Gates highlights, "reality television resituates discourses of racial representation within the specificities of its generic conventions"; Gates further argues that the genre "thrives on the tensions that result from the multiple versions of 'reality' . . . [emanating] from the shows' narratives, the types of individuals cast to participate, and audiences' own lived experiences as racialized and gendered persons. ${ }^{67}$ Leah Aldridge (Kimble's sister and L.A. Hair cast member) explains her experience on reality television thusly: "It's a little like being in a Petri dish. I'm real, all of the other cast members were real, the space was real . . . but when observed together under certain conditions, there's no telling what might emerge." 68 In this context, the fourth season of L.A. Hair builds its narrative arc from the tension that results when toptier stylists with very different intersectional backgrounds-like Kim Kimble and Jonathan Antin-negotiate creative control and start a business.

In the celebrity styling world, Antin is the perfect foil for Kimble. As early as 2005, both Kimble and Antin were identified as the US industry's top celebrity stylists. When a special issue of the trade magazine Women's Wear Daily (WWD) featured nine "big name celebrity 
stylists ... with product lines designed to bottle their talent," Kimble was ranked high on the list, second only to Antin. ${ }^{69}$ Given the gender disparity of the list-only two of the nine stylists were identified as women-their proximate rankings suggest a battle of the sexes. But as Kimberle Crenshaw's work has shown, "the intersection of racism and sexism factors into Black women's lives in ways that cannot be captured wholly by looking at the race or gender dimensions of those experiences separately." ${ }^{\text {"70 }}$ The longstanding, systemic disparity between white men and Black women, in the labor market and beyond, serves as an important framework for the tensions documented in L.A. Hair's fourth season. Antin's entitled manner and "Beverly Hills" persona-the result of his privileged power position and affiliation with clientele like Brad Pitt and Madonna-seem to fuel Kimble's lack of trust in him, leading to uneasy moments on the show.

One of the pleasures of L.A. Hair is that Kim Kimble doesn't put up with Jonathan Antin's antics. Antin's first appearance on L.A. Hair is as a guest in the third season. In "Clash of the Big Wigs" (season 3 episode 5, 2014), Antin asks Kimble to supply a wig for one of his celebrity clients. The episode, largely set in Antin's then-new Beverly Hills' salon (Jonathan \& George Salon), shows Antin and Kimble battling for creative control of the styling process. Antinknown for his acerbic manner of speaking-continually cites his years in the industry (28 years to Kimble's 20) and status as a Beverly Hills salon owner. In return, Kimble protests Antin's disrespectful tone, suggests that his ideas are outdated, and warns him not to embarrass her in front of the client (which he still does). When Antin officially joins the cast of L.A. Hair in the fourth season, a major dramatic arc forms as Kimble and Antin collaborate on a line of wigs, with Antin as an investor in Kim's product line. ${ }^{71}$ Because Kimble is a wig specialist, their venture heavily depends on Kimble's knowledge of the African-American hair community and market. At one point, Antin uses the confessional-a standard device of the reality show format-to educate viewers about this target market: "In the African-American wig industry, we're talking about somewhere in the area of 300 million [US] dollars-worth of business a year. This is an area that's untapped." 72 Given longstanding Black hair industry events like the Bronner Bros. convention ("the largest multicultural beauty trade show in the world"73), Antin's confession begs the question: Untapped by whom?

At first, the Kimble-Antin collaboration seems mutually beneficial, with Kimble benefiting from Antin's experience launching hair care products and Antin benefiting from Kimble's technical, esthetic, and community knowledge. As the season progresses, however, Kimble grows frustrated with Antin: he continually prioritizes his brand and needs, shows up late to a vendor meeting that Kimble has arranged, and buys out one of her specialized supplies. In episode seven ("A Hair-Raising Proposal" 2015), a celebratory toast quickly sours when Kimble discovers that Antin has drafted their business contract as a 35-65 split, in his favor (Figure 3[a] and [b]). ${ }^{74}$ When the season concludes at the Bronner Bros. convention in Atlanta, Kimble is surprised to find Antin in attendance. By the season's "Confidential Finale" (a recap of the season with cast members), hopes for a Kimble-Antin partnership are over.

L.A. Hair features fabulous styles and an entertaining mix of comedy and family melodrama, but it's in the face of Mr. Beverly Hills himself that the show fully emphasizes the contours of the Kimble hair dynasty. Early in the fourth season, Kimble and Antin return to Kimble Hair Studio to find her stylists joking around in a seemingly unprofessional manner. Antin 

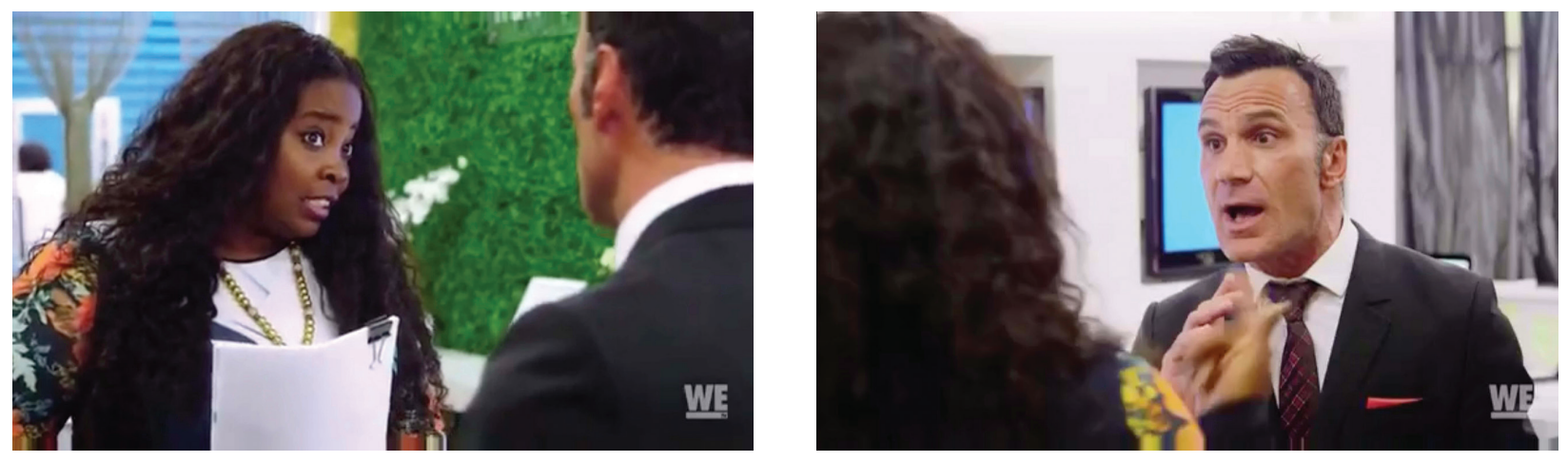

Figure 3. A deal goes south between (a) Kim Kimble and (b) Jonathan Antin.

immediately reprimands the staff and leaves, angered that they are disrespecting Kimble's brand. Kimble's reprimand goes further: "You have completely embarrassed me in front of this man. He's over there in Beverly Hills, with his fabulous salon. They already look down on us, and ya'll are over here clowning." ${ }^{75}$ Kimble's fury with her staff reveals the underlying tensions of her interactions with Antin: here, Kimble's emphasis on Beverly Hills stands in for the larger inequities around race and class that this geographic location symbolizes. With Jas and Leah literally standing behind Kim, the Kimble brand seems to be flexing its dynastic power. ${ }^{76}$

The tensions between Kimble and Antin may be no surprise, given their highly competitive field and personal differences. But the complexity of Kim Kimble's celebrity/stylist split is illustrated by the Twitter controversy that erupted around her appearance with Nicki Minaj, the multi-hyphenate rapper, in Elle magazine (June 2018). ${ }^{77}$ In one shot, photographed by Karl Lagerfeld, Minaj appears in a light-colored fur coat and black veiled hat; her floor-length, straight black tresses are held and brushed by Kimble, who stands directly behind her in the shot. Because stylists are typically hidden from view, it is striking that Kimble appears in the high fashion spread-at the request of Lagerfeld himself. ${ }^{78}$ Yet, online critiques soon circulated: at face value, the image exploits the visual contrast between Minaj's light attire and Kimble's dark attire to seemingly differentiate their skin tones and presumed social positions. ${ }^{79}$ While colorist critiques are warranted in a world where Black women of all skin tones remain underrepresented in mainstream media, supporters of the image rightly note that it depicts two well-paid, self-made Black women at the top of their respective games-and that this spotlight is especially significant for a beauty professional. ${ }^{80}$ Through a unique set of strategies and skills, Kimble has earned her visibility; unfortunately, the spotlight can be bittersweet.

More work on this topic remains to be done, but one thing seems clear: Kimble's trajectory as a Black, female, celebrity stylist is historically significant. But it's not just because celebrity stylists have largely been white men. It is also-and perhaps more importantly so-because Kimble has broken into the ranks of Hollywood through a matrilineal line of Black hairstylists. Kimble knows hair and is especially gifted in imagining and articulating new styles for clients (and by extension, us). With many years in the profession, Kimble 
knows how to navigate and negotiate her own narrative, media representation, and nearly every facet of hair production-from high fashion shoots to music videos to feature films. But recognition continues to be uneven: the spectacular hairstyles Kimble designed for A Wrinkle in Time seemed well suited for a 2018 Oscar nomination, but her artistry and technique were not recognized by the Academy or the Make-Up Artists \& Hair Stylists (MUAHS) Guild Awards. ${ }^{81}$ As Black women's long and growing history of hair styling in media production continues to unfold, scholars must be more attentive to the ways that intersectionality and power operate above and below the line so we can heed Kristen J. Warner's call to "consider the historical and discursive ways creative men and women laborers of color have survived" and better address how the media industries and general public view (nonwhite) professionals in the field. ${ }^{82}$

${ }^{1}$ Priscilla Peña Ovalle is an Associate Professor of Cinema Studies at the University of Oregon and President-Elect of the Society of Cinema and Media Studies (2019-21). Her current research on the production and performance of hair in music videos and commercials builds from her first book, Dance and the Hollywood Latina: Race, Sex, and Stardom (Rutgers, 2011).

2 "About Kim Kimble," WE tv LLC, http://www.wetv.com/shows/la-hair/cast/ kim-kimble (accessed March 10, 2018).

${ }^{3}$ This essay is the first step in my larger project about intersectionality and the production and performance of hair in music videos and commercials. While hair has long been a topic of scholarly inquiry in fields like Anthropology and Black Feminist Studies, Media Studies has only recently begun to address hair at length. With the exception of Costume, Makeup, and Hair, edited by Adrienne L. McLean, very little scholarship dedicated to the industrial and artistic production of hair on screen currently exists. Adrienne McLean, ed. Costume, Makeup, and Hair (New Brunswick, NJ: Rutgers University Press, 2016).

4 "Hairdressers, Hairstylists, and Cosmetologists: Diversity," Data USA, https:// datausa.io/profile/soc/395012/\#gender (accessed March 12, 2018).

${ }^{5}$ Adrienne McLean, "Introduction," in Costume, Makeup, and Hair, ed. Adrienne McLean (New Brunswick, NJ: Rutgers University Press, 2016), 6.

${ }^{6}$ Marianne Dougherty, "Broad City," American Salon: Official Publication of the National Hairdressers and Cosmetologists Association, May 2016, 144-55.

${ }^{7}$ Ibid., 145.

${ }^{8}$ Ibid.

${ }^{9}$ Ibid.

${ }^{10}$ Ralina L. Joseph, Postracial Resistance: Black Women, Media, and the Uses of Strategic Ambiguity (NY: NYU Press, 2018), 35. Joseph identifies "postrace" as "a fabricated realm where race-blind fiction supplanted racialized fact."

${ }^{11}$ Molly Prior, "Beautybiz: Hair Care," WWD: Women's Wear Daily 189 (118, 2005): 24.

12 Julia Kirk Blackwelder, Styling Jim Crow: African American Beauty Training during Segregation (College Station: Texas A\&M University Press, 2003), 3. 
${ }^{13}$ Kathy Peiss, Hope in a Jar: The Making of America's Beauty Culture (NY: Henry Holt, 1998), 70.

${ }^{14}$ Blackwelder, Styling Jim Crow, 152.

15 Ibid., 3-4.

16 There is something more to be said about Chicago as a site of production. This is where Kimble's mother was raised and, as Blackwelder notes, remains "home to Johnson Products, one of the few remaining minority-owned cosmetic firms." Blackwelder, Styling Jim Crow, 12.

17 "About Kim Kimble," WE tv LLC, http://www.wetv.com/shows/la-hair/cast/ kim-kimble (accessed March 10, 2018).

${ }^{18}$ Interview with Author.

19 "Ann Wadlington," Variety online, last modified June 17, 1993, https://variety. com/1993/scene/people-news/ann-wadlington-107921/.

${ }^{20}$ Interview with Author.

${ }^{21}$ Interview with Author.

${ }^{22}$ Interview with Author.

${ }^{23}$ Ibid.

${ }^{24}$ Ibid.

${ }^{25}$ Ibid.

${ }^{26}$ The correlation between hair and music has played a crucial role in African American media history. In the network era, the Black-owned hair-care and cosmetics company Johnson Products was a key sponsor of the syndicated television program Soul Train (1971-2006).

${ }^{27}$ Priscilla Peña Ovalle, Dance and the Hollywood Latina: Race, Sex, and Stardom (New Brunswick, NJ: Rutgers University Press, 2011): 144.

${ }^{28}$ bell hooks, Black Looks: Race and Representation (Boston, MA: South End Press, 1992), 65.

${ }^{29}$ Ibid., 70.

${ }^{30}$ Given my larger research project's focus on intersectionality and the production/ performance of hair in music videos and commercials, I was immediately drawn to Kimble's body of work.

${ }^{31}$ Ovalle, Dance and the Hollywood Latina, 144.

${ }^{32}$ Ayana D. Byrd, and Lori L. Tharps, Hair Story: Untangling the Roots of Black Hair in America (NY: St. Martin's Press, 2001), 17.

${ }^{33}$ Paulette Caldwell, "A Hair Piece: Perspectives on the Intersection of Race and Gender," Duke Law Journal 1991 (2, April 1991): 365-96.

${ }^{34}$ Ibid., 391-93. I am especially moved by Caldwell's concluding thoughts:

Creating a society that can be judged favorably by the way it treats the women of its darkest race need not be the work of black women alone, nor will black women be the exclusive or primary beneficiaries of such a society. Such work can be engaged in by all who are willing to take seriously the everyday acts engaged in by black women and others to resist racism and sexism and to use these acts as the basis to develop legal theories [or other interventions, like media initiatives] 
designed to end race and gender subordination. (Caldwell, "A Hair Piece," 396; emphasis added by author)

${ }^{35}$ Ibid., 383.

${ }^{36}$ Stacey Stowe, "New York City to Ban Discrimination Based on Hair," The New York Times, February 18, 2019, https://www.nytimes.com/2019/02/18/style/hair-dis crimination-new-york-city.html.

${ }^{37}$ Kobena Mercer, "Black Hair/Style Politics," new formations, no. 3 (Winter 1987): $35-54$.

${ }^{38}$ A similarly racist phenomenon occurs with studio makeup in 1930s Hollywood. See Kirsty Sinclair Dootson, "The Hollywood Powder Puff War': Technicolor Cosmetics in the 1930s," Film History 28 (1, 2016): 107-31.

${ }^{39}$ McLean, "Introduction," 10.

${ }^{40}$ Ibid., 5.

${ }^{41}$ Alicia Annas, "The Photogenic Formula: Hairstyles and Makeup in Historical Films," in Hollywood and History: Costume Design in Film, ed. Edward Maeder (Los Angeles, CA: Thames and Hudson/Los Angeles County Museum of Art, 1987), 57.

${ }^{42}$ Richard Dyer, White (NY: Routledge, 1997).

${ }^{43}$ Caldwell, "A Hair Piece," 390. Also, see "We unravel the hidden story behind headwraps," Facebook video (via Racked), 2:39, produced by Caitlin Brown and written by Angela Fichter, accessed April 10, 2017, https://www.facebook.com/refinery29/ videos /1619284988101687/.

${ }^{44}$ My larger project addresses the technical production and performance of hair, especially in terms of racialized gender and sexuality. How and why hair care commercials emphasize light and movement, through conventions like "gloss," "shine," and "bounce" are key factors of this inquiry. The hair care commercial portfolio of director/photographer Rebbecca Blake ("Hair Montage") illustrates some of these conventions while the web tutorial by director/cinematographer Matthew Rosen ("Tutorial on Cinematography for Shooting Hair") highlights the methods behind these esthetics. Rebecca Blake, "Rebecca Blake: Director \& Photographer," 1:29, accessed August 10, 2018, http://rebeccablake.com/hair-montage/. Matthew Rosen, "Tutorial on Cinematography for Shooting Hair," YouTube video, 3:40, November 17, 2014, https://www.youtube.com/watch?v=YLg9SGa9tIQ.

${ }^{45}$ Dougherty, "Broad City," 150.

${ }^{46}$ Alex Apatoff, "The Person Most Shocked by Beyoncé's Short Hair: Her Stylist!" People, August 8, 2013, https://people.com/style/the-person-most-shocked-bybeyonces-short-hair-her-stylist/.

${ }^{47}$ Nicki Minaj and Kim Kimble have since parted ways. See Maiysha Kai, "Not a Good Look? Nicki Minaj Reportedly Splits with Longtime Hairstylist Kim Kimble and Glam Squad," The Glow Up (blog), August 29, 2018, https://theglowup.theroot.com/nota-good-look-nicki-minaj-reportedly-splits-with-lon-1828673926.

${ }^{48}$ Kimble's post reads, "Instagram doesn't create licensed or professional hairdressers. We all get negative comments sometimes, but why try to drag someone else into it when we can support each other? Sending positive vibes and support to licensed hairstylists." As Maiysha Kai, Managing Editor of the Black lifestyle site The Glow-Up, notes, licenses are important but not the sole marker of artistry. Maiysha Kai, "Splitting Hairs: Celeb Hairstylists Kim Kimble and Tokyo Stylez Sparked a Shady 
Debate Over Legitimacy," The Glow Up (blog), August 23, 2018, https:/ / theglowup. theroot.com/splitting-hairs-celeb-hairstylists-kim-kimble-and-toky-1828554311.

${ }^{49}$ Interview with Author.

${ }^{50}$ Sidney Madden, "Beyond Beychella: The Rise of Women of Color on America's Biggest Festival Stage," The Record: Music News from NPR, April 20, 2018, https://www. npr.org/sections/therecord/2018/04/20/603053145/beyond-beychella-therise-of-women-of-color-on-americas-biggest-festival-stage. Racism and misperceptions about audience similarly reify the myth that so-called Black films don't do well in international markets; such mainstream perceptions may also limit the visibility of Kimble's brand and products. See Leah Aldridge's work on the marketing and circulation of Hollywood's "brands of cinematic blackness." Leah Aldridge, "Mythology and Affect: The Brands of Cinematic Blackness of Will Smith and Tyler Perry," Spectator 31 (1, Spring 2011): 41-47.

${ }^{51}$ Miranda Banks, "Gender Below-the-Line: Defining Feminist Production Studies," in Production Studies: Cultural Studies of Media Industries, ed. Vicki Mayer, Miranda J. Banks, and John Thornton Caldwell (NY: Routledge, 2009), 89.

${ }^{52}$ Matt Stahl, "Privilege and Distinction in Production Worlds: Copyright, Collective Bargaining, and Working Conditions in Media Making," in Production Studies: Cultural Studies of Media Industries, ed. Vicki Mayer, Miranda J. Banks, John T Caldwell (NY: Routledge, 2009), 61.

${ }^{53}$ Banks observed this gendered dynamic when speaking with female practitioners, noting that specific jobs-like costuming or stunt work-are "socially constructed though gender." Banks, "Gender Below-the-Line," 87.

${ }^{54}$ Ibid., 90. Also see Erin Hill, Never Done: A History of Women's Work in Media Production (New Brunswick, NJ: Rutgers University Press, 2016), 68.

${ }^{55}$ Vicki Mayer, Below the Line: Producers and Production Studies in the New Television Economy (Durham, NC: Duke University Press, 2011), 20.

${ }^{56}$ Here, I heed Mercer's call to evaluate "Black hair-styling . . . as a popular art form articulating a variety of aesthetic 'solutions' to a range of 'problems' created by ideologies of race and racism." Mercer, "Black Hair/Style Politics," 34.

${ }^{57}$ McLean, "Introduction," 5.

58 "Makeup Power," Los Angeles Business Journal (Los Angeles, CA), September 23, 2002, "IATSE Local 706" Core Collection File, Margaret Herrick Library, Los Angeles, California, United States. The article notes that the pay disparity between makeup artists and hairstylists - with stylists getting less-may be linked to a gendered history of the departments.

${ }^{59}$ Miliann Kang, The Managed Hand: Race, Gender, and the Body in Beauty Service Work (Berkeley: University of California Press, 2010), 12, 20. Also see Arlie Hochschild, The Commercialization of Intimate Life: Notes from Home and Work (Berkeley: University of California Press, 2010).

${ }^{60}$ Stylists may provide emotional support as confidantes; for high-profile clients, this may require confidentiality or additional pre-performance support before a shoot or show.

${ }^{61}$ Dougherty, "Broad City," 150.

${ }^{62}$ Two other programs-a BBC 4 audio documentary entitled The Salon (2003) and an announced (but perhaps never executed) reality series set in hair salons by Fox 
TV Studios called Making the Cut-precede Blow Out, but neither show had the same longevity as Blow Out or the competition hairstyling show Shear Genius, for which Antin served as a judge. See "The Salon," The Documentary Podcast, BBC, accessed January 31, 2019, http://www.bbc.co.uk/programs/p03qh0rm. Also see Denise Martin, "Fox salon-set skein makes reality 'Cut," Variety, September 28, 2003, https://variety.com/2003/scene/news/fox-salon-set-skein-makes-real ity-cut-1117893104/.

${ }^{63}$ Shelli Weinstein and Debra Birnbaum, "Cable Networks Undergo Extreme Makeovers with New Logos, Slates," Variety, October 17, 2014, https://variety.com/2014/tv/ news/we-tv-trutv-oxygen-give-themselves-makeovers-1201329969/.

${ }^{64}$ Joe Otterson, "WE tv Rebrand as 'Real Reality Network' Pays Off in Spades," Variety, June 30, 2017, https://variety.com/2017/tv/news/we-tv-reality-series-marcjuris-1202477432/.

65 Jason Lynch, "AMC Networks Doesn't Need a Big Upfront Event. It Has The Walking Dead," Adweek, April 19, 2016, https://www.adweek.com/tv-video/amc-networksdoesn-t-need-big-upfront-event-it-has-walking-dead-170901/.

${ }^{66}$ Caldwell, "A Hair Piece," 391.

${ }^{67}$ Racquel Gates, "Keepin' It Reality Television," in Watching While Black: Centering the Television of Black Audiences, ed. Beretta E. Smith-Shomade (New Brunswick, NJ: Rutgers University Press, 2013), 142.

${ }^{68}$ Leah Aldridge, Text message to author, February 1, 2019.

${ }^{69}$ Prior, "Beautybiz: Hair Care," 22.

${ }^{70}$ Kimberle Crenshaw, "Mapping the Margins: Intersectionality, Identity Politics, and Violence against Women of Color," Stanford Law Review 43 (6, 1991): 1244. My use of the capital "B" in "Black"-like my interchangeable use of "Black" and "AfricanAmerican"-follows the logic Crenshaw provides in footnote number six on this page: "I capitalize 'Black' because 'Blacks, like Asians, Latinos, and other 'minorities,' constitute a specific cultural group and, as such, require denotation as a proper noun."

${ }^{71}$ Around this time, a short piece in Modern Salon promoting L.A. Hair focused on Antin by stating,

For salon owners and stylists considering launching their own product line, the new reality series L.A. Hair will be of particular interest. On the show, entrepreneur and celebrity stylist Jonathan Antin offered valuable business advice with fellow stylist Kim Kimble, who's looking to expand her hair care line.

Elizabeth Jakaitis, "5 Tips for a Successful Beauty Launch from L.A. Hair's Jonathan Antin," Modern Salon, August 10, 2015, https://www.modernsalon. com/article/32255/5-tips-for-a-successful-beauty-launch-from-la-hairs-jonathan-antin.

${ }^{72}$ L.A. Hair, season four episode one, "I'm the Boss, Hunty!," aired July 30, 2015, on WE tv.

${ }^{73}$ Malin Fezehai, "At the 'Hairdresser's Fashion Week,' Celebrating Black Beauty Meet the People Who Gather for the Extravaganza Known as the Bronner Bros. Show in Atlanta," New York Times, February 23, 2018, https://www.nytimes. com/2018/02/23/style/black-women-hair-beauty.html?nytapp = true. 
${ }^{74}$ In the "Confidential Finale," Antin contends that the 65-35 split is an "industry standard." In many ways, the season highlights the communication differences between Antin and Kimble, perhaps due to the reasons I have already outlined.

${ }^{75}$ L.A. Hair, season four episode three, "Nail'd By Naja," aired August 13, 2015, on WE tv.

76 The show and season, which include more twists and turns than can be recounted here, definitely promote the idea that "blood is thicker than water."

${ }^{77}$ Devin Gordon, "The Queen Returns: After a Four-Year Hiatus, Nicki Minaj Is Back with a Banging Album and a New Outlook on Life," Elle, June 13, 2018, https:// www.elle.com/culture/celebrities/a21239224/nicki-minaj-queen-interview-julycover/.

${ }^{78}$ Nicki Minaj (@nickiminaj), "My Hair Stylist @kimblehaircare Was Told by Karl HIMSELF to Stay in the Shot. We Contained Ourselves in front of Him Then Walked to the Back \& Started Screaming \& Spazzing Out [wailing emoji]. She Was Thrilled! @elleusa [heart emoji]." Instagram photo, June 13, 2018, https://www.instagram. com/p/Bj-SuxRhdOt/?taken-by = nickiminaj.

${ }^{79}$ Maiysha Kai, "What's Wrong with This Picture? Critics of Nicki Minaj's Latest Elle Shoot Cry Colorism," The Glow Up (blog), June 14, 2018, https://theglowup.theroot. com/whats-wrong-with-this-picture-critics-of-nicki-minajs-1826812973.

${ }^{80}$ Ibid.

${ }^{81}$ Kimble was nominated for an "Outstanding Hairstyling for a Miniseries, Movie or a Special" Emmy in 1997 and nominated for "Best Contemporary Hair Styling for Television Mini-Series or Motion Picture Made for Television" by the Hollywood Makeup Artist and Hair Stylist Guild in 2017.

${ }^{82}$ Kristen J. Warner, "Strategies for Success? Navigating Hollywood's 'Postracial' Labor Practices," in Precarious Creativity: Global Media, Local Labor, eds. Michael Curtin and Kevin Sanson (Berkeley: University of California Press, 2016), 184.

\section{Bibliography}

Aldridge, Leah. "Mythology and Affect: The Brands of Cinematic Blackness of Will Smith and Tyler Perry." Spectator 31, no.1 (Spring 2011): 41-47.

Annas, Alicia. "The Photogenic Formula: Hairstyles and Makeup in Historical Films." In Hollywood and History: Costume Design in Film, edited by Edward Maeder, 52-77. Los Angeles, CA: Thames and Hudson/Los Angeles County Museum of Art, 1987.

Banks, Miranda. "Gender Below-the-Line: Defining Feminist Production Studies." In Production Studies: Cultural Studies of Media Industries, edited by Vicki Mayer, Miranda J. Banks, and John Thornton Caldwell, 87-98. New York: Routledge, 2009.

Blackwelder, Julia Kirk. Styling Jim Crow: African American Beauty Training during Segregation. College Station: Texas A\&M University Press, 2003.

Byrd, Ayana D., and Lori L. Tharps. Hair Story: Untangling the Roots of Black Hair in America. New York: St. Martin's Press, 2001.

Caldwell, Paulette. "A Hair Piece: Perspectives on the Intersection of Race and Gender." Duke Law Journal 40, no. 2 (April 1991): 365-96. 
Crenshaw, Kimberle. "Mapping the Margins: Intersectionality, Identity Politics, and Violence against Women of Color." Stanford Law Review 43, no. 6 (1991): 1241-99.

Dootson, Kirsty Sinclair. "'The Hollywood Powder Puff War': Technicolor Cosmetics in the 1930s." Film History 28, no. 1 (2016): 107-31.

Dyer, Richard. White. New York: Routledge, 1997.

Gates, Racquel. "Keepin' It Reality Television." In Watching While Black: Centering the Television of Black Audiences, edited by Beretta E. Smith-Shomade, 141-56. New Brunswick, NJ: Rutgers University Press, 2013.

Hill, Erin. Never Done: A History of Women's Work in Media Production. New Brunswick, NJ: Rutgers University Press, 2016.

Hochschild, Arlie. The Commercialization of Intimate Life: Notes from Home and Work. Berkeley: University of California Press, 2010.

hooks, bell. Black Looks: Race and Representation. Boston, MA: South End Press, 1992.

Joseph, Ralina L. Postracial Resistance: Black Women, Media, and the Uses of Strategic Ambiguity. New York: NYU Press, 2018.

Kang, Miliann. The Managed Hand: Race, Gender, and the Body in Beauty Service Work. Berkeley: University of California Press, 2010.

Mayer, Vicki. Below the Line: Producers and Production Studies in the New Television Economy. Durham, NC: Duke University Press, 2011.

McLean, Adrienne L., ed. Costume, Makeup, and Hair. New Brunswick, NJ: Rutgers University Press, 2016.

Mercer, Kobena. "Black Hair/Style Politics." new formations, no. 3 (Winter 1987): 33-54.

Ovalle, Priscilla Peña. Dance and the Hollywood Latina: Race, Sex, and Stardom. New Brunswick, NJ: Rutgers University Press, 2011.

Peiss, Kathy. Hope in a Jar: The Making of America's Beauty Culture. New York: Henry Holt, 1998.

Stahl, Matt. "Privilege and Distinction in Production Worlds: Copyright, Collective Bargaining, and Working Conditions in Media Making." In Production Studies: Cultural Studies of Media Industries, edited by Vicki Mayer, Miranda J. Banks, and John Thornton Caldwell, 54-67. New York: Routledge, 2009.

Warner, Kristen J. "Strategies for Success? Navigating Hollywood's 'Postracial' Labor Practices." In Precarious Creativity: Global Media, Local Labor, edited by Michael Curtin and Kevin Sanson, 172-185. Berkeley: University of California Press, 2016. 